\title{
Primjena tradicijskih elemenata kožnog prsluka u suvremenoj kolekciji ženske odjeće
}

\author{
Irena Šabarić, Anita Koturić, Beti Rogina-Car \\ Sveučilište u Zagrebu Tekstilno-tehnološki fakultet, Prilaz baruna Filipovića 28, 10000 Zagreb, \\ Hrvatska
}

irena.sabaric@ttf.unizg.hr

Izvorni znanstveni rad

DOI: $10.34187 /$ ko.69.1.4

\begin{abstract}
Sažetak
Kolekcija ženske odjeće prikazana u radu inspirirana je kožnim elementima etna muške i ženske narodne nošnje Slavonije. Obzirom na bogatstvo i različitost nošnji izdvojen je jedan kožni element s kožuha koji je razrađen na nov način i primijenjen u suvremenoj kolekciji odjeće. Puno pažnje posvetilo se ručnoj izradi i kvaliteti pa ova kolekcija ima i obilježja visoke mode.

U likovnom dijelu, kroz skice, je razrađena odabrana tema odnosno element. Razrađeni su modeli te mjesta gdje će se i na koji način aplicirati kožni elementi i ogledala. Kolekcija element nošnje prebacuje u jednostavne, pročišćene odjevne predmete, čime stvara kontrast između staroga i novoga, tradicije i moderne. Prikazuje sadašnjost, suvremenu kolekciju nastalu na temeljima bogate prošlosti i tradicije. Rezultat je prikazan u obliku realizirane kolekcije ženske odjeće s izrađenim kožnim etno aplikacijama.
\end{abstract}

Ključne riječi: kožni elementi, etno, narodna nošnja, suvremena moda

\section{Uvod}

Bogata kulturna baština Hrvatske obogaćena je tragovima prijašnjih kultura naroda koji su obitavali na njenom području. Kulturna baština je kolektivno dobro koje pripada prošlosti, sadašnjosti i budućnosti. Narodna nošnja je tradicijska i povijesna odjeća koja postoji unutar pojedinih regija, država ili članova neke skupine. Većinom spada u kulturnu baštinu odnosno kulturno naslijeđe. Nošnja je jedno od najizražajnijih sredstava za iskazivanje lokalne, regionalne $\mathrm{i}$ etničke pripadnosti. $U$ današnje vrijeme, nošnja izdvojena iz cjelokupnog kulturnog i društvenog konteksta u kojem je nastala, te u posve promijenjenom okružju i dalje zrači kao simbol nacionalnog identiteta $[1,2,3]$.

Narodna nošnja je tradicionalni stil odjeće negrađanske populacije u predindustrijsko doba. Obuhvaća sve odjevne predmete (donje rublje, osnovnu i vanjsku odjeću) za svakodnevne i svečane prigode i za sva godišnja doba. Narodnu nošnju karakterizira većinom jednostavan kroj upotreba prirodnih materijala. Nadalje, takva odjeća imala je dugovječnost oblika i nije bila podložna modnim trendovima. Sirovina koja se koristila za izradu narodnih nošnji bila je uvjetovana onome što nudi prirodni okoliš određenog kraja (lan, konoplja, pamuk, vuna, svila, koža, krzno, perje itd.), a taj izbor materijala bio je i najprikladniji klimatskim uvjetima. Narodna nošnja, također, odražava povijesnu sudbinu i dodire s drugim kulturama. Komponente nošnje isticale su obiteljski i društveni položaj pojedinca, dob, poziv itd. Ukrašavanje nošnje pokazivalo je tadašnje razumijevanje ljepote. Primjenom civilizacijskih postignuća i industrijski proizvedenih materijala dolazi do nestanka rukotvorina, narodna nošnja postupno nestaje iz svakodnevne upotrebe. Reprezentativni primjerci narodne nošnje danas se čuvaju u etnografskim muzejima i zbirkama kao dokumenti materijalne kulture prošlih razdoblja. Narodna nošnja skladom boja, bogatstvom oblika idekorativnom sofisticiranošću ima visoki položaj u narodnoj umjetnosti predstavlja autentično hrvatsko kulturno dobro [4, 5].

Obzirom na prirodna obilježja hrvatskih područja, klimu te grane tradicionalne ekonomije narodna nošnja dijeli se na: odjeću jadranskih pomoraca i otočana - krojem, oblikom i sastavom prikladna blagoj mediteranskoj klimi; čista suprotnost je odjeća gorštaka koja je teška i topla kako bi pružila zaštitu od gorske hladnoće. Nošnje hrvatskih seljaka zbog izloženosti različitih susjednih kultura te odjeći viših društvenih slojeva imale su u svojoj strukturi odraz povijesnih i umjetničkih stilova. Naprimjer u košulji iz Dalmatinske zagore očituje se rimska tunika; u istarskoj odjeći Gotika; u jadranskoj bluzi s bijelim vezom i ušivenom čipkom renesansa; na posavskim prslucima i zimskim kaputima barok; u slavonskom zlatnom vezu rokoko [4].

$U$ radu je dan naglasak na dijelove narodne nošnje koji su izrađeni iz kože. $\mathrm{Na}$ temelju kožnih odjevnih predmeta ili dijelova odjevnih predmeta izrađena je mini kolekcija suvremene odjeće inspirirana elementima etna, posebice kožnim prslucima narodnih nošnji Hrvatske. Razradom zadane teme izrađene su cvjetne kožne aplikacije, koje su aplicirane na odjevne predmete u suvremenu kolekciju od pet outfita.

\section{Materijali i metode}

\subsection{Materijali}

Nastala kolekcija jesen/zima inspirirana je etnom - narodnom nošnjom Slavonije. Inspiracija je proizašla iz jedne od brojnih dekorativnih tehnika korištenih u izradi nošnje - bogato ukrašenih malih prsluka, velikih zimskih kaputa. Služi se ogledalcima i kožnim aplikacijama kako bi jednostavnim odjevnim predmetima dala drugu dimenziju u teksturi. Kolekcijom dominiraju neutralni tonovi, od svijetle, hladne sive, pješčanih sivih, pa do tople nude, završavajući s tamnosivom. Materijali korišteni u kolekciji su poliester, svila, skaj, koža i ogledalca. Odjevni predmeti se mogu međusobno kombinirati na više načina [3]. Nastala kolekcija tradicijske elemente narodne nošnje pretvara u suvremenu kolekciju pročišćenih oblika i neutralnih boja. Inspirirana tradicijom i bogatom kulturnom baštinom Hrvatske kolekcija postaje spoj suvremenog i tradicijskog na moderan i suvremen način.

\subsection{Izdvojeni odjevni predmeti narodne nošnje korišteni za inspiraciju - Staklene aplikacije na odjevnim predmetima}

\subsubsection{Kožuščić}

Kožuščić je naziv za kratki, mali ženski kožuh koji zimi čini gornji odjevni predmet nošnje. Izrađen je bez rukava s velikim prednjim polukružnim izrezom i kopčanjem s prednje strane na tri velika dugmeta, uz pomoć kožnih petlji. Postoje dvije vrste kožuščića: svakidašnji i pokajni.

Pokajni kožuh je manje cifran (ukrašen). Nosio se u pokajnim prigodama ili su ga nosile starije osobe. S unutarnje strane kožuščića nalazi se koža šarenoga bijelo-smeđega runa, a s vanjske strane koža je presvučena crnim štofom. Po cijeloj rubnoj, donjoj strani našivena je ukrasna kožica u tamno zelenoj boji. Uz prednju sredinu našiveni su širi pojasevi, a na stražnjem dijelu dva polukružna pojasa. Sve je dopunjeno žuto-crvenim kožicama te crvenim ili plavim rubnim perlicama. Sa obje strane kožušiča aplicirani su stilizirani cvjetovi od istih tamnozelenih kožica. (sl. 1) [3, 6, 7].

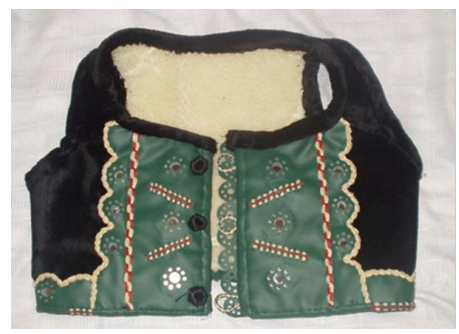

a)

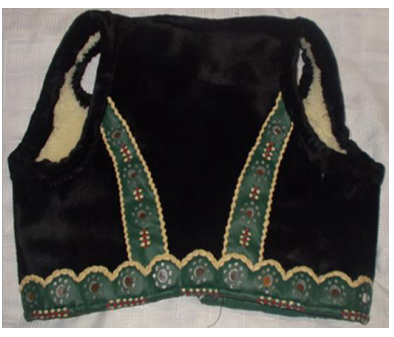

b)
SI. 1 Pokajni kožuh: a) prednji dio, b) stražnji dio, okolica Slavonskog Broda [3] 
Drugi kožuh je puno bogatiji u boji i u većini slučajeva potpuno spunjen šarenim ili jednobojnim stilizirano izrezanim kožnim aplikacijama, ispod kojih su postavljeni komadići zrcala. Njegova cijela površina ispunjena je geometriziranim i cvjetnim ornamentima (sl. 2, 3) [3, 6, 7].

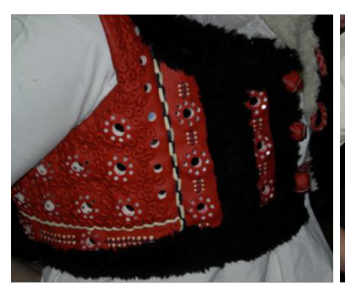

a)

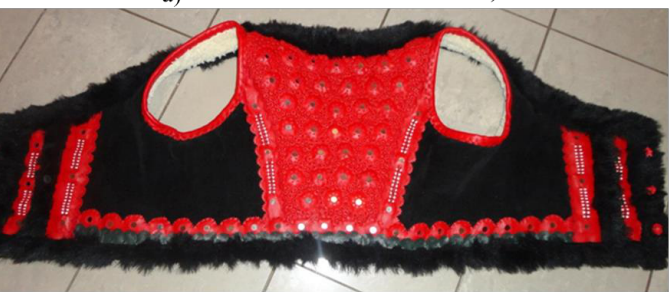

b)

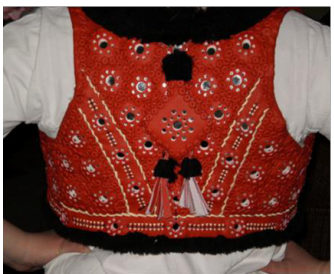

b)
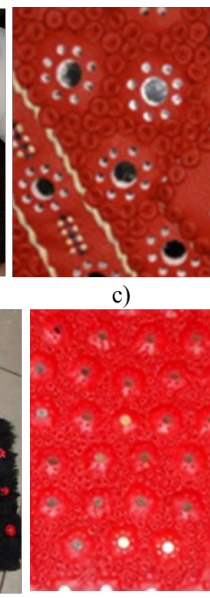

c)

SI. 2 Kožuh iz Slavonskog Broda: a) Prednji dio, b) Stražnji dio, c) Prikaz uvećane kožne aplikacije sa stakalcima [3]

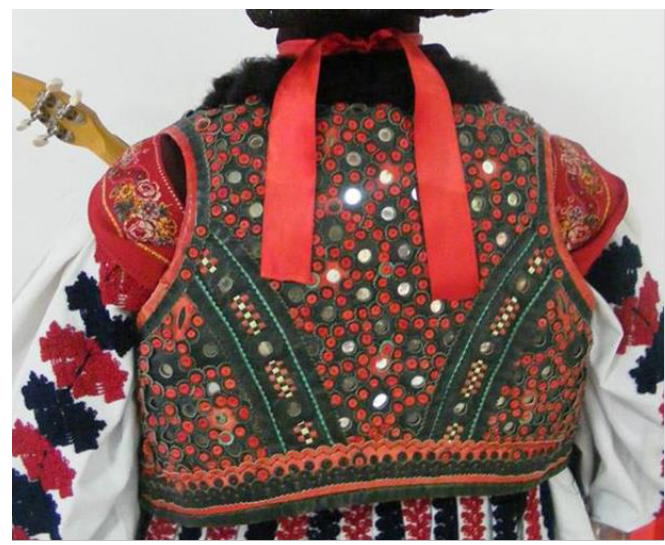

a)

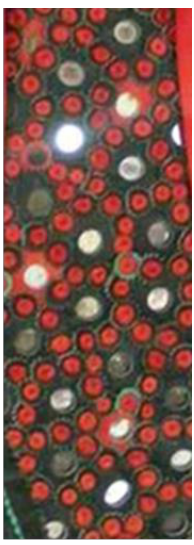

b)
SI. 3 Kožuh iz Retkovaca: a) Stražnji dio, b) Prikaz uvećane kožne aplikacije sa stakalcima [3]

\subsubsection{Muški pršnjak}

Pršnjak je naziv za muški krzneni odjevni predmet do pasa, bez rukava. Proizvod je kožuhara - krznara. Izrađen je od svijetlosmeđe kože, s prednje i stražnje strane zatvoren, a u cijelom donjem dijelu lagano je kružno krojen. Kopčanje se nalazi s lijeve bočne strane uz pomoć petlji i četiri kožna dugmeta, te na lijevom ramenu s dva dugmeta. Na području struka apliciran je crni i crveni kožni pojas dopunjen plavo-žutom pletenicom. Cijela prednja strana i donji polukružni dio ispunjeni su bogatim kožnim aplikacijama biljnog sadržaja: stiliziranim granama, cvjetovima i laticama ispod kojih su ubačena ogledalca koja stvaraju blještaviji dojam. Kožne aplikacije su u crvenoj, žutoj, zelenoj, crnoj i plavoj boji. Na unutarnjoj strani bilo je bijelo umjetno krzno, a po vratnom otvoru umjetna crna maca. Ovakav bogato ukrašen pršnjak u prošlosti nosili su momci i mlađi oženjeni muškarci za svečanije prilike, preko košulje od domaćeg tkanja, uz hlače rajtozne (radne gaće, hlače od debelog tkanja, najčešće samta), opanke i obojke, ili čizme (sl. 4) [3, 7].

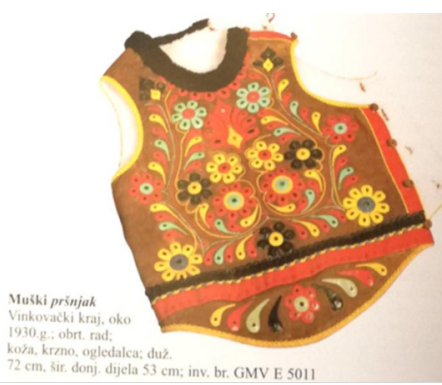

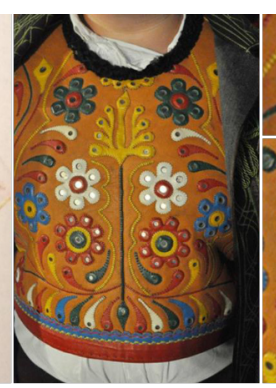

b)

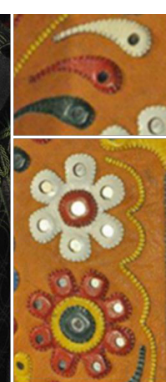

c)
SI. 4 Muški pršnjak a) Vinkovci, b) iz privatne zbirke c) Prikaz uvećane kožne aplikacije sa stakalcima [3]
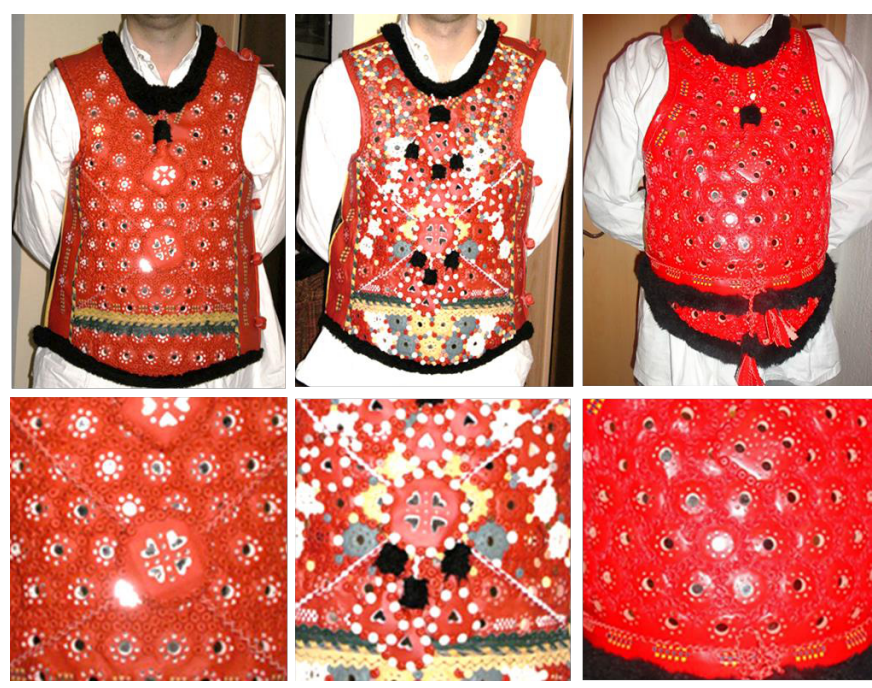

SI. 5 Varijacije pršnjaka na području Slavonskog Broda uz prikaz uvećane kožne aplikacije sa stakalcima [3]

\subsubsection{Veliki muški cifrani kožuh}

Veliki kožuh nosili su muškarci zimi u svakodnevnim i svečanim prilikama; mlađi više cifran, stariji s manje uresa. Prvi kožusi izrađeni su od čiste bijele kože bez aplikacija. Kožuh novijeg vremena ima obojanu kožu i cifran je. Koža je obojana u svijetlosmeđu boju, a sama površina kožuha bogato je aplicirana komadićima kožica u raznim bojama - tirše (tanka koža u boji koja se reže na vrlo uske remenčiće za ukrašavanje odjeće), svjetlije i tamnije zelenoj, žutoj i ljubičastoj s prevladavajućom crvenom bojom. Ispod kože su umetnuti komadići stakla, ogledalca. Elementi koji se apliciraju su stilizirani florealni oblici cvijeća, grana, koji se u različitim kombinacijama bogato ukrašavaju površine kožuha. Na stražnjoj strani visi dugačka rojta (ukras od niti vezanih na gornjem, a slobodnih na donjem kraju), kićanka na upletenim vezicama. Duga je oko sto deset centimetara. Na prednjici ima dva džepa, a zatvara se gumbima s kožnim petljama. Unutrašnjost kožuha je od ovčjeg krzna ovce rackulje koja se koristi zbog dužine runa. Rubovi su ukrašeni janječim runom. Za razliku od muškaraca koji nose kožuh s rukavima u ovim krajevima su žene nosile isključivo kožuhe bez rukava.(sl. 6) [3, 7].

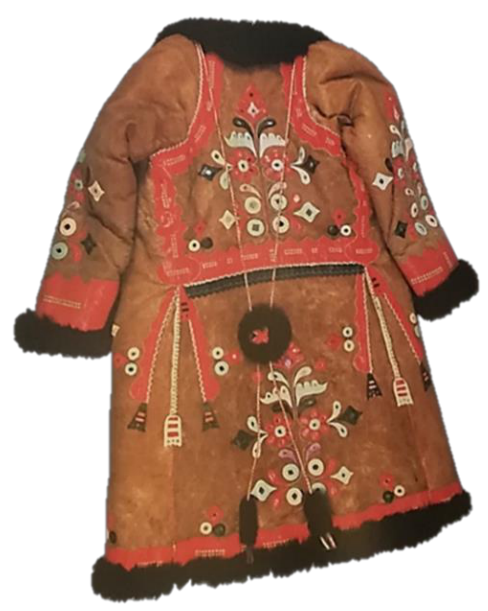

a)

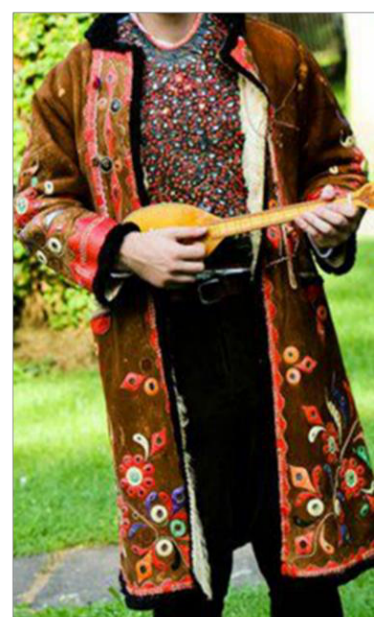

b)
SI. 6 Cifrani kožuh: a) Stražnji dio kožuha, Komletinci; b) Prednji dio kožuha, Privatna zbirka [3]

\section{Eksperimentalni dio}

Prva faza izrade kožnih etno aplikacija obuhvaća eksperimentiranje s materijalom - kožom. Kako koža reagira na tehnike kroz koje prolazi da bi se dobila kožna aplikacija sukladno osmišljenom dizajnu, odnosno gotov izgled kožnih aplikacija spremnih za našivanje. Uslijedilo je proučavanje reakcije kože na izlaganje toplini, istezanje, postotak skupljanja, te promjenu dimenzija. Potrebno je dobiti kožnu aplikaciju u dobrom omjeru s odjevnim predmetima, kako ne bi došlo do deformacije u formi i materijalu. Dimenzije aplikacija određene su i na temelju veličine ogledalaca čiji promjer iznosi $20 \mathrm{~mm}$. Ogledalca predstavljaju prvi sloj na koji se potom našivaju kožne aplikacije. Ogledalca su uzeta kao orijentir prema kojemu je izrađena prva verzija aplikacija stiliziranog 
cvjetnog uzorka. Nakon što su napravljene prve rupičaste cvjetne aplikacije od probnog materijala, dvije od tanjeg i debljeg skaja, kako bi se odredio utjecaj šupljina na čvrstoću i oblik materijala, dobiveni su podaci o idealnoj debljini materijala, te su određene točne dimenzije rupica na uzorku (sı. 7) [3].
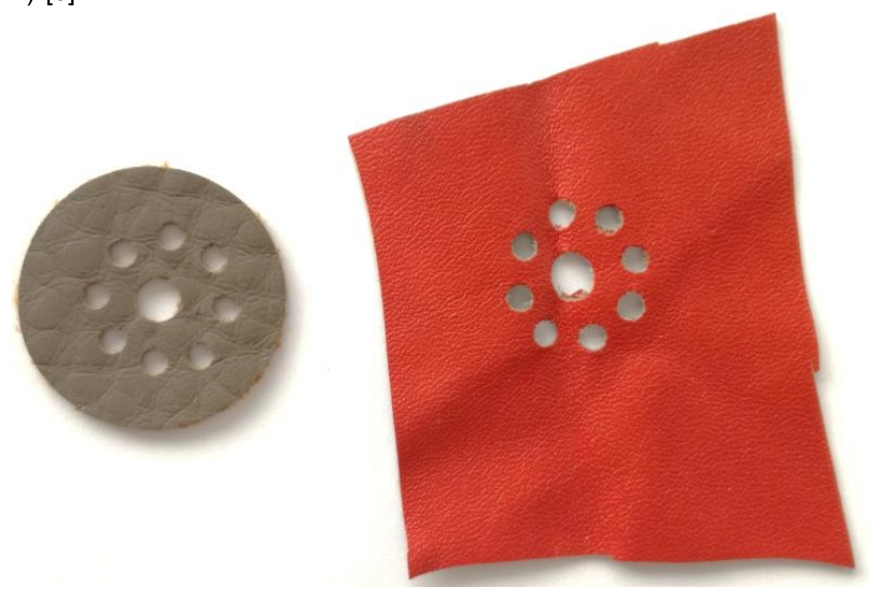

SI. 7 Rupičaste aplikacije u probnim materijalima [3]

$\mathrm{Na}$ temelju proba određene su dimenzije aplikacija za manja ogledalca promjera $20 \mathrm{~mm}$ : vanjski krug, tj. radijus cijele aplikacije $36 \mathrm{~mm}$; unutarnji, središnji krug - tučak $5 \mathrm{~mm}$; okolni kružići - latice $3 \mathrm{~mm}(\mathrm{sl} .8,9)$ [3].

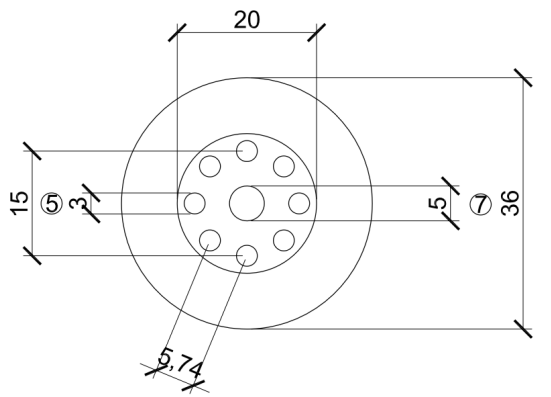

SI. 8 Shematski prikaz manje aplikacije sa svim mjerama [3]

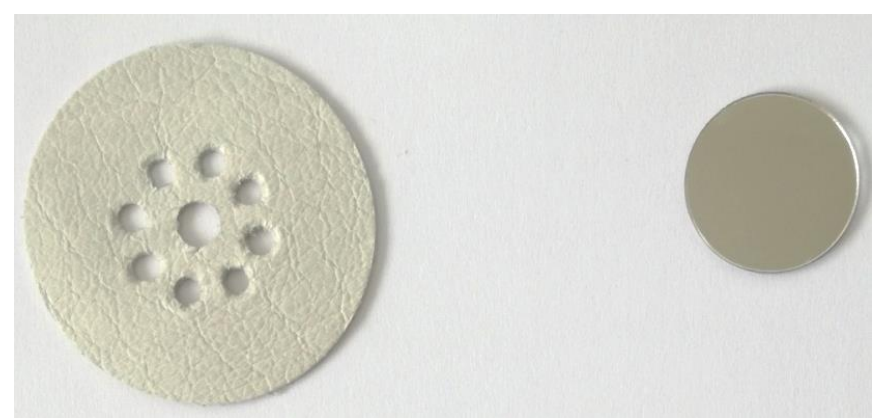

SI. 9 Ogledalce i gotova manja rupičasta aplikacija [3]

Dimenzije rupičastih aplikacija za veća ogledalca šesterokutnog oblika (dimenzije stranica $20 \mathrm{~mm}$ ) su: vanjski krug, tj. veličina aplikacije 55 $\mathrm{mm}$; unutarnji, središnji krug $10 \mathrm{~mm}$; okolni kružići - latice, promjera 5 $\mathrm{mm}$ (sl. 10, 11) [3].

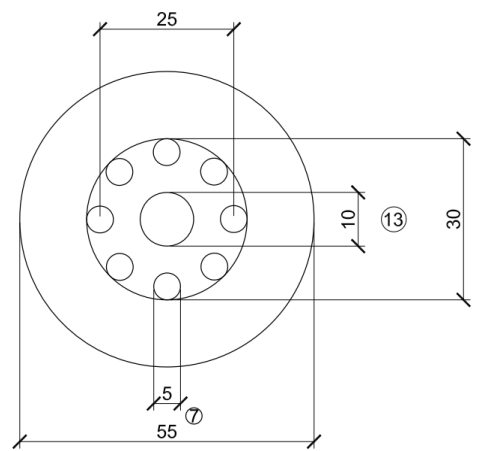

SI. 10 Shematski prikaz veće aplikacije sa svim mjerama [3]

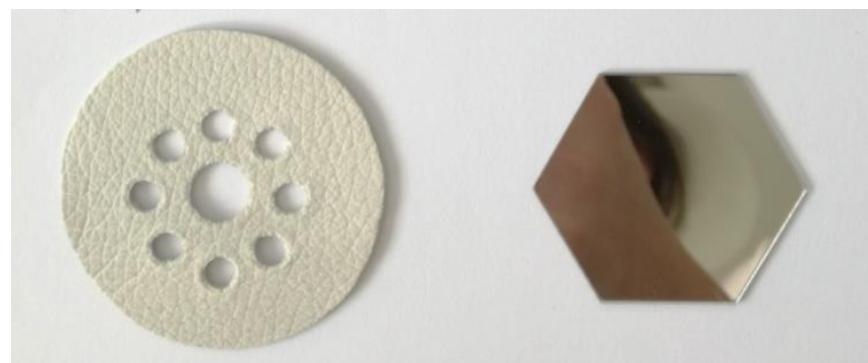

SI. 11 Ogledalce i gotova veća rupičasta aplikacija [3]

Posljednja dimenzija koju je bilo potrebno odrediti su male kružne kožne aplikacije koje dolaze u trećem sloju, nakon ogledalaca i rupičastih kružnih aplikacija. Našivaju se po čitavom rubu rupičastih kožnih aplikacija. Prije našivanja, prolaze proces zagrijavanja, taljenja, pri čemu se njihov prvobitni oblik i dimenzije mijenjaju. Postotak promijene oblika i dimenzija ovise o debljini i kvaliteti štavljenja kože. Postupak je slijedeći: nakon bušenja kružni komadići kože stavljaju se na indirektan izvor topline, pri čemu dolazi do skupljanja. Probni komadići kožnih aplikacija različitih dimenzija korišteni su za izračun postotka skupljanja na osnovi kojeg su dobivene mjere željenih kožnih kružića: dimenzija za izrezivanje $16 \mathrm{~mm}$, koje se nakon zagrijavanja i skupljanja promijene te im dimenzije iznose 10-12 $\mathrm{mm}$, ovisno o debljini kože (sl. 12) [3].

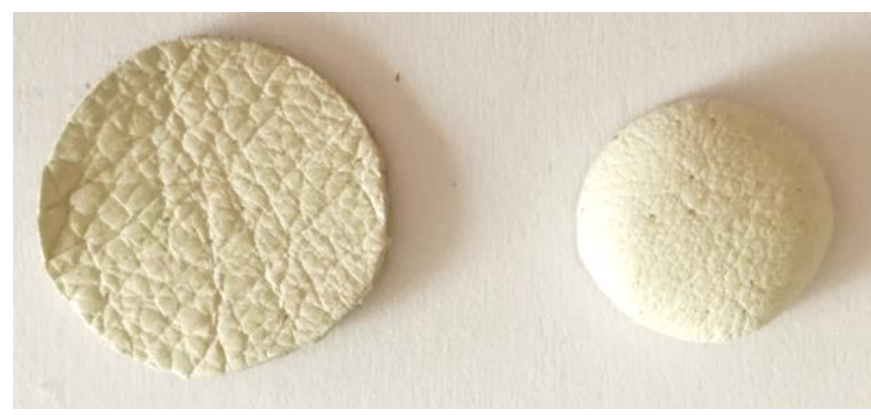

SI. 12 Kožni kružić prije i nakon zagrijavanja [3]

\subsection{Izrada kožnih aplikacija}

Nakon prve faze u kojoj su definirane dimenzije kožnih aplikacija slijedi izrada. Uzimajući u obzir potreban veliki broj kožnih aplikacija, desetak tisuća, javlja se pitanje kako olakšati i ubrzati njihovu izradu. Odgovor na postavljeno pitanje je izrada kožnih aplikacija pomoću metalnih pomagala izrađenih prema dimenzijama aplikacija, te pomoću lohajzli (probijač za kožu), kojima se na udar izbijaju pravilni kružni komadići kože (sl. 13) [3].
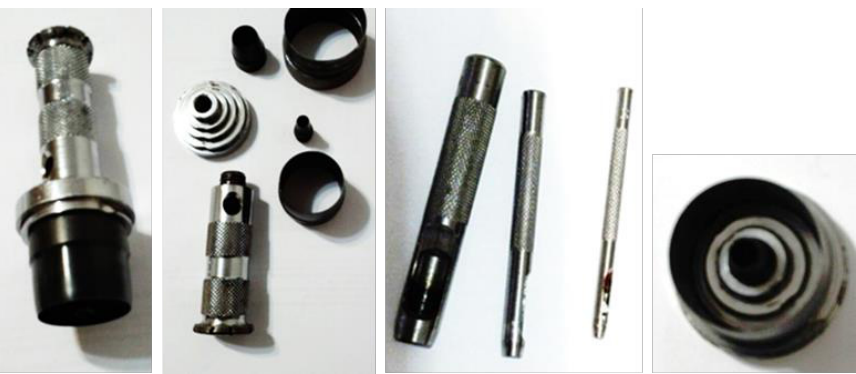

SI. 13 Lohajzle i metalni nastavci za izradu [3]

Svaka rupica se zasebno buši. Prethodno napravljene sheme, skice s mjerama, pravilnim razmacima i omjerima rupica, poslužile su za izradu metalnih pomagala za jednostavniju i praktičniju izradu aplikacija (sl. 14) [3].

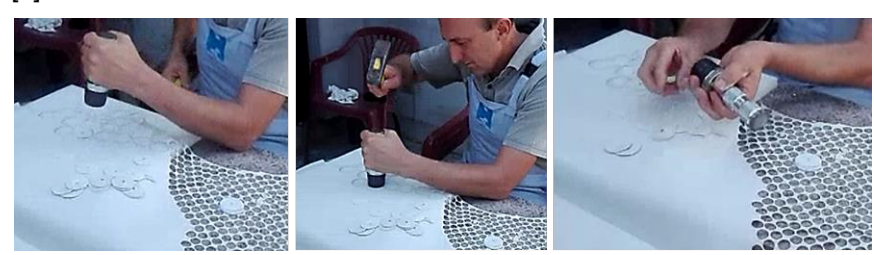

SI. 14 Postupak izrade vanjskog i središnjeg kruga kožnih aplikacije [3]

Nakon što su napravljeni svi vanjski krugovi, buše se male unutarnje rupice. Za izradu su korištena dva metalna dijela istokarena prema skicama kožnih aplikacija, te vanjskim promjerima nastavaka lohajzli(sl.15,16) [3]. 

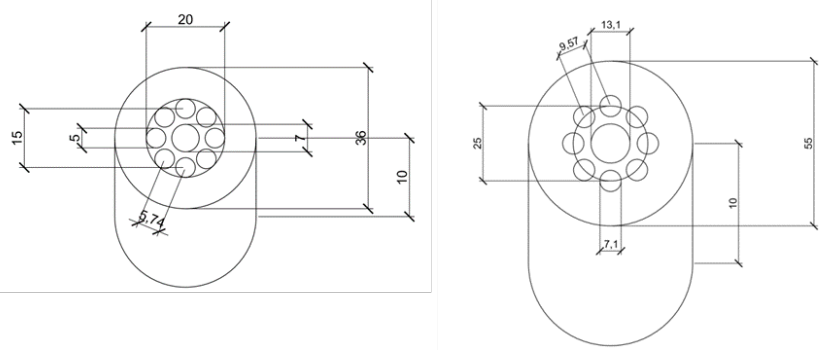

SI. 15 Shematski prikaz metalnog pomagala za izradu rupica na kožnim aplikacijama: a) manji, b) veći [3]
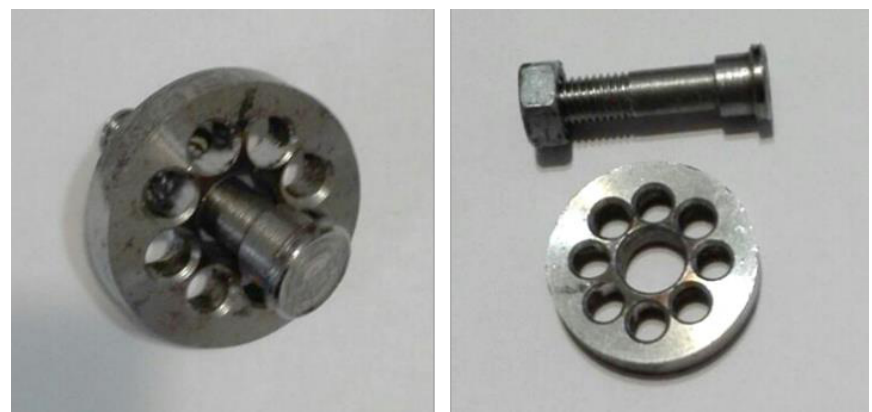

SI. 16 Izrađeni metalni dijelovi za izradu kožnih aplikacija [3]

Bušenje unutarnjih rupica započinje stavljanjem kožne aplikacije na čvrstu podlogu u kojoj je izbušena rupica veličine središnjeg unutarnjeg kruga aplikacije. Na nju se stavlja prethodno opisani istokareni metalni dio. Vijkom kroz srednji krug učvrste se slojevi kože, da ne dođe do pomicanja. $\mathrm{Na}$ ovaj način mogu se bez pomicanja napraviti okolni kružići. Obzirom da se kožne aplikacije stavljaju između podloge i metalnog dijela, ovakav način izrade omogućuje istodobno bušenje više slojeva kože.

Međutim, svaki kružić na aplikaciji mora biti probušen zasebnim udarcem lohajzli, s nastavkom odgovarajuće veličine. Isti postupak vrijedi i za veće aplikacije (sl. 17) [3].

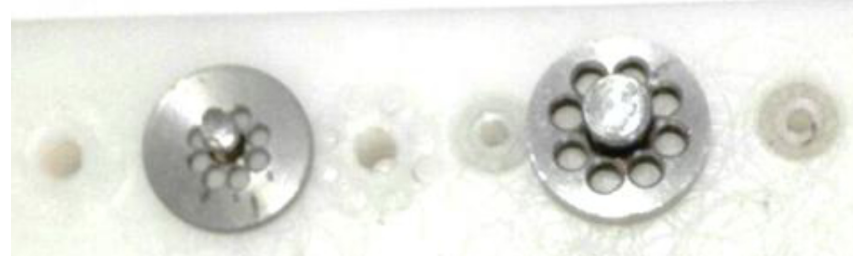

SI. 17 Metalni dijelovi učvšćeni sa podlogom [3]

Treća vrsta kožnih aplikacija, koje su izrađene jesu one najmanje - kružići promjera $16 \mathrm{~mm}$. Izrađene su također, pomoću lohajzli i nastavka određene veličine. Nakon što su sve aplikacije izbušene, mali kožni kružići podvrgnuti su toplini, pri čemu se skupljaju. Na plamen srednje jačine stavlja se metalna podloga na koju dolaze kožni kružići. Svaki kožni kružić izložen je toplini 1-2 min, ovisno o debljini materijala i brzini skupljanja. Nakon što se skupe do željene veličine, skidaju se sa zagrijane podloge, te se isti postupak nastavlja sa sljedećim kružićima, dok se svi napravljeni kožni kružići ne obrade. Pri zagrijavanju, osim skupljanja kože, dolazi do napuhavanja, čime nastaju napuhani, izdignuti kožni kružići (sl. 18) [3].

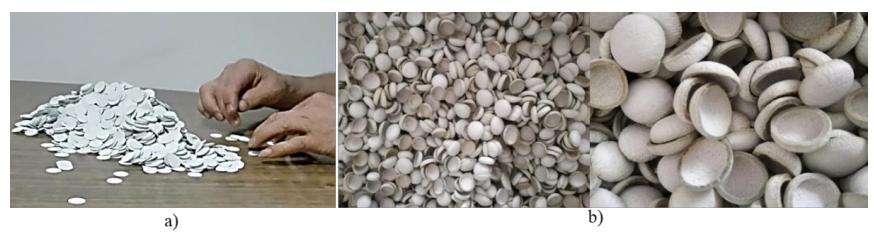

SI. 18 Najmanje kožne aplikacije: a) izbušeni kružni komadići kože, b) gotovi izgled kožnih kružić [3]

\subsection{Apliciranje}

Nakon što su odjevni predmeti izrađeni do određene faze, slijedi apliciranje izrađenih elemenata od kože i ogledalaca u tri koraka. Prvi korak: posložiti kožne rupičaste aplikacije na odabrani odjevni predmet. Potrebno je odrediti točan položaj kožnih aplikacija na odjevnom predmetu, kako bi se mogla fiksirati ljepilom ogledalca koja dolaze ispod kožnih aplikacija. Premda su ogledalca korištena za izradu kožuha izvorno bila staklena, u kolekciji su zamijenjena plastičnim ogledalcima. Plastična ogledalca svojom masom, debljinom i obradom primjerenija su aplikaciji na odabrani materijal bez bojazni od oštećenja (sl. 19) [3].

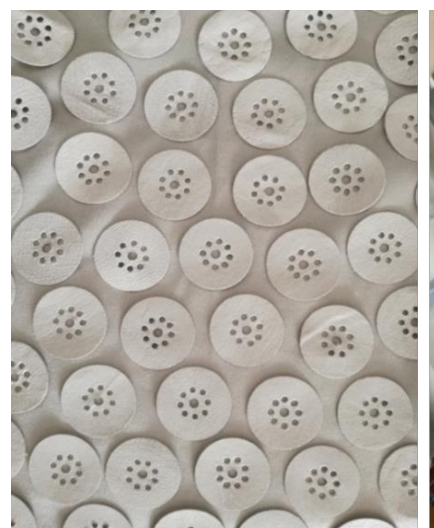

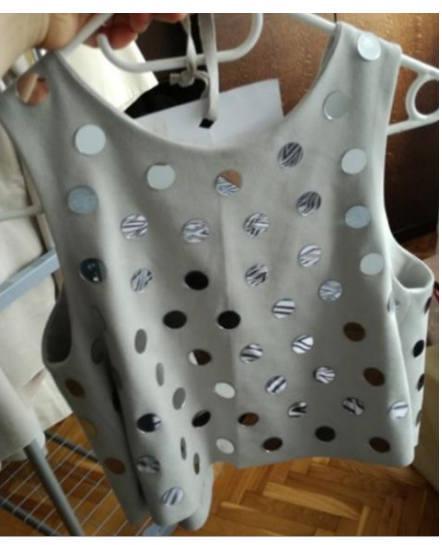

b)
SI. 19 Prvi korak: a) raspoređivanje kožnih rupičastih aplikacija na odjevni predmet, b) pričvršćena ogledalca [3]

Nakon što se ljepilo osušilo i učvrstilo ogledalca, dolazi drugi korak: našivanje rupičastih kožnih aplikacija preko ogledalaca. Rupičasti dio kožne aplikacije centrira se iznad ogledalaca i ručno uz rub kružno našiva na odjevni predmet (sl. 20) [3].

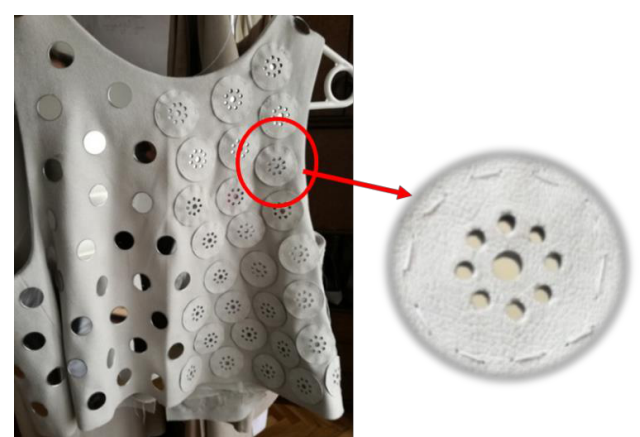

SI. 20 Drugi korak: našivanje rupičastih kožnih aplikacija na ogledalca

Treći i posljednji korak je našivanje najmanjih napuhanih kožnih kružića na rub rupičaste kožne aplikacije. Najmanji kožni kružići našivaju se kroz sredinu, najnapuhaniji dio, na način da ga konac povuče prema tkanini, pri čemu se stvori udubina u sredini. Postupak se ponavlja dok se ne ispune sve kožne rupičaste aplikacije. Za našivanje korištena je posebna igla za kožu, koja je zašiljena s tri strane (sl. 21). Na slici 22 prikazane su našivene kožne aplikacije [3].

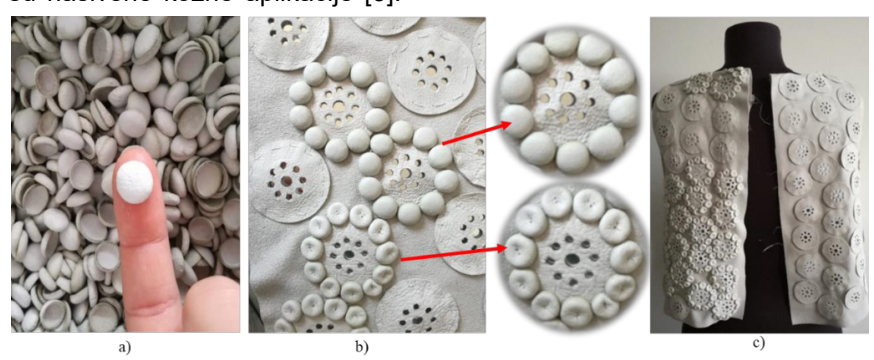

SI. 21 Treći korak: a) kožni kružići spremni za našivanje, b) našivanje najmanjih napuhanih kožnih kružića na rub rupičaste kožne aplikacije, c) odjevni predmet u procesu našivanja kožnih aplikacija

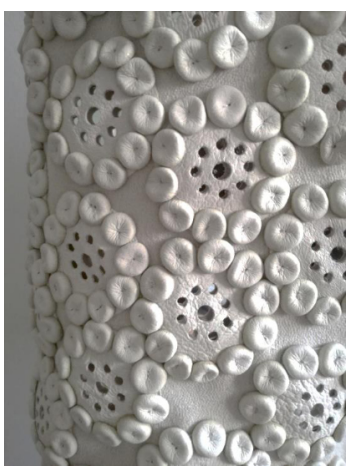

SI. 22 Prikaz našivenih kožnih aplikacija [3] 


\subsection{Realizirana kolekcija}

Realizirana kolekcija s etno kožnim aplikacijama inspiriranim Slavonskom narodnom nošnjom prikazana je na slikama 23-27 [3]. Može se primijetiti da je prema novim smjernicama i održivosti u modi, na slici 23 , iskorišten i dio kože koji bi obično predstavljao otpad, a ovdje se idealno uklopio kao kožni vanjski dio džepa. Ostali realiziran modeli zahtijevali su dugotrajnu izradu i veliku preciznost i umješnost dizajnera $s$ obzirom da se svaki kožni detalj, kako je prethodno opisano, našivao ručno.

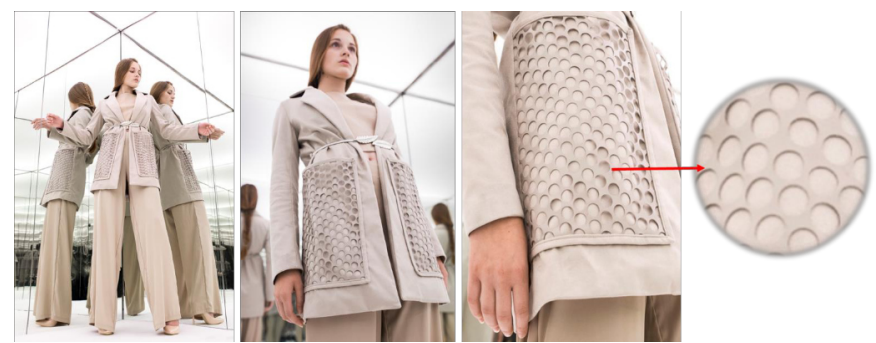

SI. 23 Prikaz realiziranog 1. outfita s detaljima - etno kožnim aplikacijama

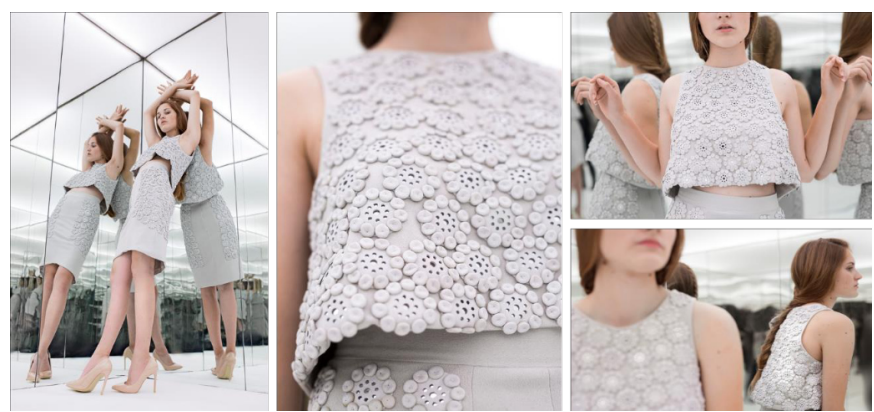

SI. 24 Prikaz realiziranog 2. outfita s detaljima - etno kožnim aplikacijama

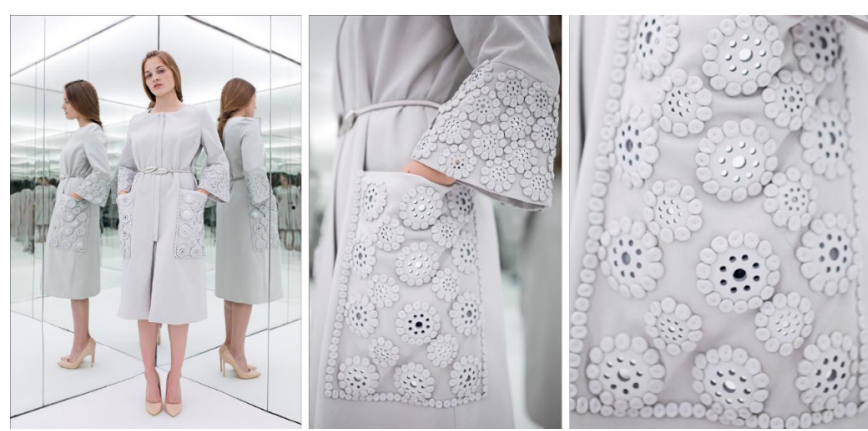

SI. 25 Prikaz realiziranog 3. outfita s detaljima - etno kožnim aplikacijama

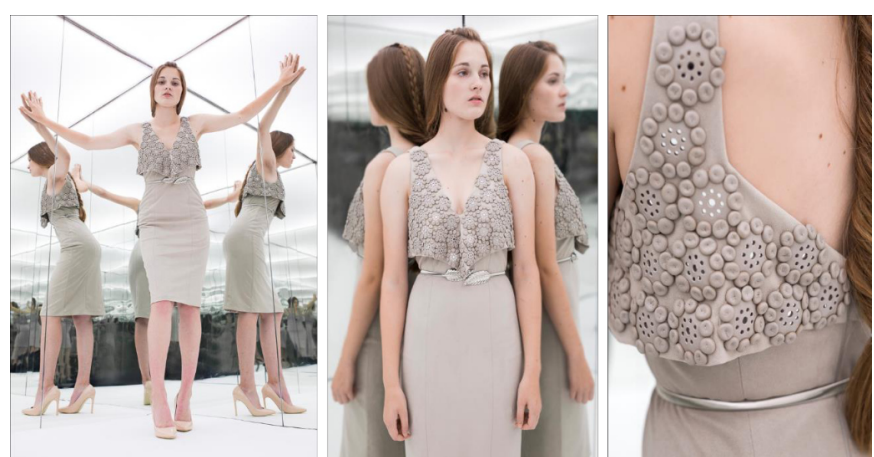

SI. 26 Prikaz realiziranog 4. outfita s detaljima - etno kožnim aplikacijama

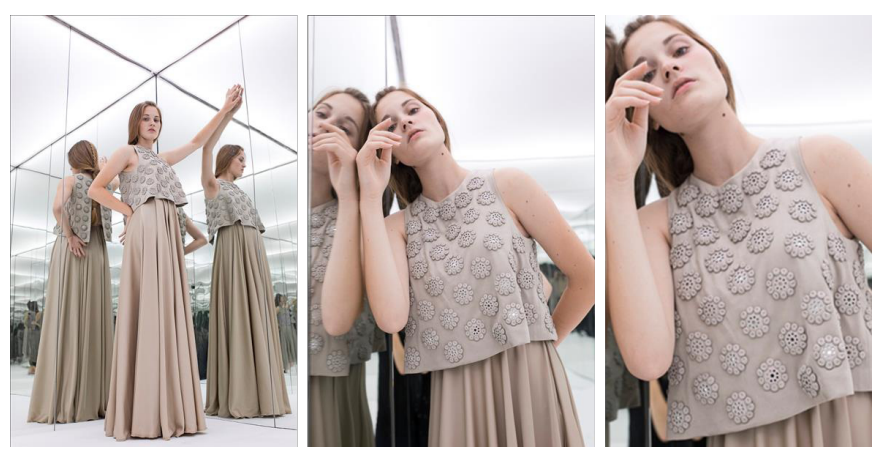

SI. 27 Prikaz realiziranog 5. outfita s detaljima - etno kožnim aplikacijama

\section{ZAKLJUČAK}

Današnji način života izbacuje tradicijsku odjeću iz svakodnevne uporabe. Zamijenila ju je suvremena odjeća poznatih brandova. No, unatoč oštrom istiskivanju iz svakodnevnog života, nošnja je uspjela pronaći svoje mjesto postavši kostimom folklornih plesnih i glazbenih izražaja, te je njeguju kulturno umjetnička društva i pojedinci. Time je nošnja sebi osigurala potrebu za održavanjem i rekonstruiranjem. Također, postala je vječna inspiracija mnogih kolekcija odjeće.

U ovom radu koristeći samo jednu od tehnika kojima je nošnja obogaćena, stvorena je kolekcija koja tradiciju uzima iz njenog konteksta, te joj daje novi život u drugom, modernom, jednostavnom, pročišćenom odjevnom predmetu. Kolekcija je inspirirana rupičastim aplikacijama stiliziranog cvjetnog uzorka ispod kojih prodiru ogledalca kao i načinom i tehnikom ručnog našivanja odabranih motiva. Rupičasti kožni dijelovi, ogledala ispupčeni kožni kružići stvaraju novu teksturu odjevnih predmeta te ga oplemenjuju na nov način. Realizirana kolekcija ne prati modne trendove nego pokazuje svoju bezvremensku ljepotu poput narodnih nošnji prema kojima je nastala. Stare tehnike ručnog rada, u spoju sa čistim linijama, mekim materijalima i nježnim siluetama, pokazatelj su koliko je zapravo bogatstvo nošnje neiscrpno i otvoreno za interpretaciju te kao takvo neiscrpan izvor inspiracije.

\section{Literatura}

Cifrić I.: Očuvanje baštine u kontekstu Europske unije, Adrias 20 (2014), 9-19.

Radauš Ribarić J.: Narodne nošnje Hrvatske-monografija, Spektar 1975, Zagreb.

Koturić A. Elementi etna u suvremenoj modi, kolekcija odjeće. Diplomski rad, Zagreb, 2017. Sveučilište u Zagrebu Tekstilnotehnološki fakultet.

Narodna nošnja. Hrvatska enciklopedija, internetsko izdanje. Leksikografski zavod Miroslav Krleža, 2020. http:// www.enciklopedija.hr/Natuknica.aspx?ID=42987, Pristupljeno: 13-11-2020

Narodne nošnje Hrvatske. http://www.hrvatskifolklor.net/php/ narodnenosnjehrvatskehf.php, Pristupljeno: 13-11-2020

Gligorević Lj.: Vodič stalnog postava Etnologija Vinkovaca i okolice - Guidebook Permanent collection Etnology of Vinkovci and its sorroundings, Gradski muzej Vinkovci, 2002. odjel, Zavičajni muzej Stjepan Gruber, Županja, 2004 